\title{
Comparative Study of the Effects of Diospyros Lycioides and Ozoreaschinziion Oral Hygiene
}

\author{
Kamanja $S^{1}$, Bock $\mathrm{R}^{1}$, Mumbengegwi $\mathrm{D}^{1}$, Mukesi $\mathrm{M}^{2}$ and Gonzo \\ $\mathbf{M}^{2 *}$ \\ ${ }^{1}$ Department of Biological Sciences, University of Namibia, Faculty of Science, \\ Namibia
}

Research Article

Volume 2 Issue 1

Received Date: April 16, 2018

Published Date: April 30, 2018

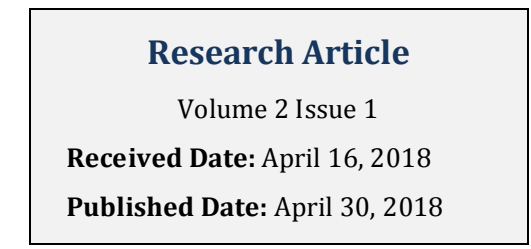

${ }^{2}$ Department of Health Sciences, Namibia University of Science and Technology, Faculty of Health and Applied Sciences, Namibia

*Corresponding author: Gonzo M, Namibia University of Science and Technology, Department of Health Sciences, P Bag 13388, Namibia, Email: mgonzo@nust.na

\section{Abstract}

The use of and search for drugs and dietary supplements derived from plants have accelerated in recent years. Botanists, microbiologists, and natural-products chemists are combing the Earth for phytochemicals and "leads" which could be developed for treatment of infectious diseases. While 25 to $50 \%$ of current pharmaceuticals are derived from plants, none are used as antimicrobials, over $80 \%$ of the world's population still relies on traditional medicine using plant extracts to provide health coverage, this is especially so in the developing world. This is a study of two plants indigenous to Namibia that are locally used for oral hygiene. The plants were collected and screened for known phytochemicals that have antimicrobial properties. Two extracts were done on each plant, one organic extract and an aqueous extracted. The phytochemical screening of plant extracts revealed the presence of saponins, anthraquinones, alkaloids and flavonoids. These compounds are known to be biologically active and therefore aid the antimicrobial activities of Diospyros lycioides and of Ozoreaschiinzi. Both plants showed antimicrobial properties against Candida albicans and Staphalococcus aureus however the most activity was noted in the organic extract.

Keywords: Indigenous plant; Antimicrobial properties; Oral hygiene

\section{Introduction}

Oral hygiene is a practice observed in many cultures and many plant parts have long been documented as means of maintaining good oral hygiene. The oral cavity houses a highly diverse composition of micro flora. The largest numbers of microorganisms are found on the tooth surfaces, especially at undisturbed sites and are called dental plaque, the microbial composition changes according to surface depending on the prevailing biological properties of the site [1-3].
Plants produce a wide variety of complex phytochemicals, and in this production, lies the potential for new antimicrobial substances. It is estimated that nearly $70 \%$ of the world's population depend largely on traditional herbal medicine to meet their primary health care needs [4]. The chewing stick was used by the Babylonians some 7000 years ago [5]. It was used by the ancient Greek, Romans and Egyptians. It is still being used in many parts of the world such as Africa, Asia and The Middle East. The toothbrush and other means of oral-care may be more accessibly today than in previous decades, however 


\section{Medicinal \& Analytical Chemistry International Journal}

many cultures still make use of chewing sticks for the relieve of dental problems. The chewing sticks including some African ones which have been reported to contain plaque inhibiting substances that can reduce bacterial colonization and plaque formation [6].

Diospyros lycioides, commonly known as the monkey plum is found on the banks of dry riverbed of central and northern Namibia, and neighboring countries. The plant known locally as the oshilugulu, omuzema and jakkalsbessie is a small tree of nearly six meters, used traditionally by the Owambo, Kavango and Herero people as a chewing stick for oral hygiene. The Diospyros lycioides is traditionally known to have other medicinal uses such as treatments for eye conditions and ointment can be made from the plant and used for pains and sprains [7].

Ozoreaschinzii, locally known as the oshifiku by the Kwanzaa people is found in the sandy woodlands of northern Namibia as a shrub, $2-3 \mathrm{~m}$ high with petiolate, oval leaves. The branches and roots are used as chewing sticks in oral hygiene and for pain relief [7].

\section{Materials and Methods}

Branches and roots of Diospyroslycioides and branches of Ozoreaschiinzi were collected from Ohangwena Region in northern Namibia. The plant material was air dried at room temperature; the dried material was then grounded into a fine powder. Fifteen grams of the grounded plant material was added to $50 \mathrm{ml}$ of distilled water. Another 15 grams of the grounded plant material was added to $50 \mathrm{ml}$ of ethanol. Both solutions were mixed thorough lyand allowed to stand for 24 hours at room temperature. They were then filtered using Whitman filter paper no.1; the solvents were removed using the rotary evaporator to obtain solid extracts. The extracts were then stored at $20 \mathrm{oC}$ before being analysed.

The crude plant extracts were screened for the presence of the following phytochemicals; saponins, anthraquinones, alkaloids and flavonoids using Thin Layer Chromatography (TLC). A positive sample containing the phytochemicals of interest was included in each run. They were then test against two lab strains of Candida albicans and Staphylococcus aureus obtained from the Department of Biological Sciences. The antimicrobial activity of the crude extracts was determined in accordance with the agar-well diffusion method described by [8].

\section{Results}

The phytochemical screening of plant extracts revealed the presence of anthroraquinones, and alkaloids in both plants. Saponins were not confirmed in the aqueous extract of the Ozoreaschinzii. Flavonoids were also not confirmed in either extracts of the Ozoreaschinzii. Well diffusion method was carried out on the aqueous and organic crude extracts of the roots and branches of Diospyros lycioides and branches of Ozoreaschinzii to test the antimicrobial activity against two selected oral pathogens at three different concentrations $[0.5,1.0,2.0 \mathrm{mg} / \mathrm{ml}]$. No inhibition zones formed around the aqueous extracts on either test organism. The plates with organic extracts all showed inhibition except Ozoreaschinzii at the concentration of $0.5 \mathrm{mg} / \mathrm{ml}$.

\section{Discussion}

Plants divert a significant proportion of their assimilated carbon and energy to the synthesis of compounds that have in obvious use in the cellular function of the plant. These secondary metabolites generally occur in low quantities and their production may be widespread or restricted to some genera, or even species.

Amongst the two solvents used in this study, the organic extracts from both plants have shown to possess antimicrobial properties against both test organisms. In a study by Shoeb H, et al. [9] alkaloids from Murrayakoenigi, commonly known as curry leaf, were extracted and tested against a variety of microbes, in which greatest activity as noted against Staphylococcus aureus. This result is agreeable to this study in which the plants were each tested for alkaloids and the phytochemical test indicated the presence of alkaloids in each plant as well as plant part, there was also appreciable activity against Staphylococcus aureus.

The presence of the flavonoids, anthraquinone and saponins, is also collaborates to the literature that discuss the antimicrobial properties of these phytochemicals. In the studies Bankole PO, et al., Nwondo UU, et al. $[3,10]$ the antimicrobial activity is associated with the presences of these phytochemicals.

The study supports the hypothesis that the plants have antimicrobial activity, however the aqueous extracts did not have any notable inhibition, even though in informal setting the solvent used is aqueous. The roots of Diospyros lycioides are more potent than the branches, however the potency of the Diospyros lycioides branch is not low enough to justify the uprooting of the plant. The results suggest that Diospyros lycioides plant is more potent than Ozoreaschinzii plant, however the result also indicate that the plant Ozoreaschinzii has potential. 


\section{Medicinal \& Analytical Chemistry International Journal}

\section{References}

1. Cowan M (1999) Plant Products as Antimicrobial Agents. Clin Microbiol 12(4): 564-582.

2. WHO (2002) Traditional Medicine: Growing Needs and Potential. WHO Policy Perspectives on Medicines. World Health Organization Geneva 2: 16.

3. Bankole PO, Adekunle AA, Oyede RT, Faparusi F, Adewole A (2012) Antimicrobial Activities and Phytochemical Screening of two Tropical Nigerian Chewing sticks. International journal of Applied Science and Technology 2(6): 131 -138.

4. Hamunyum M, Khan SA, Kim H, Na CI, Lee L (2006) Traditional knowledge and ex situ conservation of some threatened medicinal plants of Swat Kohistan Pakistan. Int J Bot 2(2): 205-209.

5. Al-Sadhan RI, Almas K (1999) Miswak(chewing stick): A cultural and scientific heritage. Saudi Dent J 11(2): 80-88.
6. Evans WC (2002) Trease and Evans' Pharmacognosy.15th ed, W.B. Saunders, London

7. Koenen VE (2001) Medicinal, poisonous and edible plants in Namibia. Klaus Hess Publishers/Verlag

8. Irobi ON, Moo-Young M, Anderson WA, Daramola SO (1994) Antimicrobial activity of the bark of Bridelia ferruginea (Euphorbiaceae). Intern J Pharmacog 34: 87-90.

9. Shoeb H, Hasan Z, Saha NK, Karim MM, Nahar N (2013) Antimicrobial activity of carbazole alkaloids from Murrayakoenigii (L) Spreng leave. Int J Med AromPlant ISSN 2249- 4340 3(2): 131-135.

10. Nwondo UU, Ngene AA, Ingoegbu CU, Obiiyeke GC (2010) Effects of fraction on antibacterial activity of crude extracts of Tamarinduindica. African Journal of biotechnology 9(42): 7108-7113. 